\title{
Geoengineering Assessment of Subgrade Highway Structural Material along Ijebu Owo - Ipele Pavement Southwestern Nigeria
}

\author{
Olumuyiwa Olusola Falowo ${ }^{1}$, Dahunsi Sunday Dayo ${ }^{2}$ \\ Faculty of Engineering Technology, Department of Civil Engineering, Rufus Giwa Polytechnic, Owo, Ondo State, \\ Nigeria $^{1,2}$
}

\begin{abstract}
Geochemical, geotechnical, and geophysical investigations were carried out along Migmatite gneiss underlain Ijebu Owo - Ipele pavement (under construction) in order to assess the suitability of the imported subgrade soil. Also Static Water Level (SWL) was obtained from five open wells along the highway. The geotechnical tests include specific gravity, grain size analysis, consistency limits, consolidation, compaction, and California Bearing Ratio (CBR), and shear strength; while geochemical tests were analyzed using X-ray fluorescence and Atomic Absorption Spectrophotometer (AAS). The results show that $\mathrm{SiO}_{2}, \mathrm{Al}_{2} \mathrm{O}_{3}$ and $\mathrm{Fe}_{2} \mathrm{O}_{3}$ constitute an average of 46.2\%, $23.30 \%$ and $26.54 \%$ respectively of the soils chemical composition. The silica: sesquioxide ratio of the samples ranges from 0.89 to 0.96 and classified as true laterite. The topsoil along the highway is made of moderately competent/competent soil with resistivity ranging from $298-924 \mathrm{ohm}-\mathrm{m}$ and thickness of $3.1-8.2 \mathrm{~m}$. The SWL varies from $3.3-5.5 \mathrm{~m}$ with an average of $4.3 \mathrm{~m}$ (moderately low). The soils are characterized by high California Bearing Ratio values, moderate shear strength $(150-200 \mathrm{kpa})$, and unconfined compressive strength $(300-420 \mathrm{kpa})$ with predominant kaolinite clay mineralogy group. The AASHTO and USCS classification system rate the soils as good and fair/good respectively.
\end{abstract}

Keywords: Silica-sesquioxide, Shear strength, Highway, AASHTO, Geotechnical investigation, Bearing capacity

\section{INTRODUCTION}

The frequently distinct engineering behaviour of naturally occurring construction materials within subtropical and tropical regions, as compared with those in temperate zones, has been identified as a key factor in determining the longterm engineering success or failure of road projects in developing countries [1] and is a function of the impact of their interaction with the road environment and the weathering processes. The majority of materials used in highway construction, such as fill materials for embankment construction, aggregates for base and surface courses, are naturally occurring materials. These materials are usually available within certain proximity to the project site and meeting certain physical and chemical characteristics. The quality of a civil engineering project depends on effective preconstruction investigation, material quality, skill and commitment of the work force. These may require understanding of existing ground conditions; properties of materials to be excavated; equipment that will be needed to excavate, grade, transport material to and from site; and dewatering below grade work if necessary; shoring to protect excavations (if need be). The sub-grade can be defined in terms of location as the upper $600 \mathrm{~mm}$ of the road foundation. For an elevated highway this will be below the embankment fill and for at-grade sections this would be immediately below the pavement section. The character of in situ sub-grade material is determined by the geological and weathering conditions of the soil-rock profiles underlying the road. The suitability of the sub-grade material is a function of internal factors such as soil-rock type and its interaction with external factors such as climate and the local moisture regime [2]. Embankments are constructed over prepared and stabilized subgrade. Typical requirement for elevated embankment includes the use of good drainable material spread in thin lifts and compacted to the required density. Where good material sources are easily available, embankment materials falling between the classification of A-1-a and A-4 per AASHTO M145 are preferred. Where a good source is not readily available, stabilization of existing materials should be considered.

This project work deals with the engineering geological assessment of selection and use of naturally occurring materials (in-situ) for pavement construction and earthwork embankments, along Iyere - Ipele roadway (under construction) in Ondo State, Southwestern Nigeria (Fig. 1), which is classified as "Trunk B" road [3], under the ownership and management of Ondo State government. The use of extreme cohesive/expansive and low bearing capacity soil as sub grade soil resulting in prolonged consolidation and unnecessary settlement of the roadway is gradually becoming a norm during construction of most Nigeria roads. Even though the coordinator of the project was 
reluctant in releasing important data as regard soil tests results for further analysis. However the attitude didn't debar the researcher in taking samples, and inspect the site condition in terms material, equipment, and manpower. One of the main reasons why highways in the country fail is that adequate knowledge of the soil situation is not obtained before the commencement of the road work. Knowledge of the soil situation helps both at the design and construction stage of the road. The subgrade should be tested and found to be adequate before usage. The soil for sub base and base course even the material for the wearing course and the pavement must be found to meet the standard before they will be accepted for usage in road construction work

The Iyere-Ipele highway is located within Owo Local Government Area of Ondo State, Nigeria. It is located between longitudes $\mathrm{E}^{\circ} 35^{\prime}$ and $\mathrm{E} 5^{\circ} 40^{\prime}$, and latitudes $\mathrm{N}^{\circ} 07^{\prime}$ and $\mathrm{N} 7^{\circ} 10^{\prime}$ (Fig. 1). The road is about $10 \mathrm{~km}$, and extended from Mobil in Owo to Ipele town. The area is characterized by gently undulating relief. The topographic elevation varies generally from less than $340-362 \mathrm{~m}$. The area is drained by rivers Ogbese and its tributaries. The drainage pattern is dendritic. The road falls within the Okemesi soil type, derived from Quartz Schist and Gneisses. The soil are very coarse textured, gravelly, pale grayish brown to brown, usually sand soils (Table 1). Also residual soils such as laterites, resulting from the weathering and decomposition of the Precambrian Basement rocks cut across the various rock types in the area. The highway pavement was constructed with/or on the lateritic materials derived from either the in-situ weathering of the underlying lithology very close to the site or brought to complement the existing ones (Fig. 2). Often very shallow over quartz rubble, associated with a topography of steep sided elongated ridges (Fig. 3). Laterites are known to be highly weathered materials rich in iron content and aluminium sesquoxides with varying content of silica and kaolinite depending on the degree of weathering and decomposition. The study area lies within the crystalline Basement Complex rocks of southwestern Nigeria. The identified lithologic units within the area include; quartzites, quartz schist, migmatite, granite and granite gneiss. However the road is founded on migmatite gneiss and quartz schist (Fig. 4). The migmatite gneiss is strongly foliated, composed of mafic minerals such as biotite, hornblende, and felsic minerals of quartz and feldspar. About $77 \%$ of the minerals are quartz, biotite and feldspar with quartz having $40 \%$ as the most dominating mineral. In general terms metamorphic classification can be considered as function of mineralogy, texture and fabric. According to Table 2, the rock underlying the highway can classified as geotechnically moderate strongly anisotropic rocks.

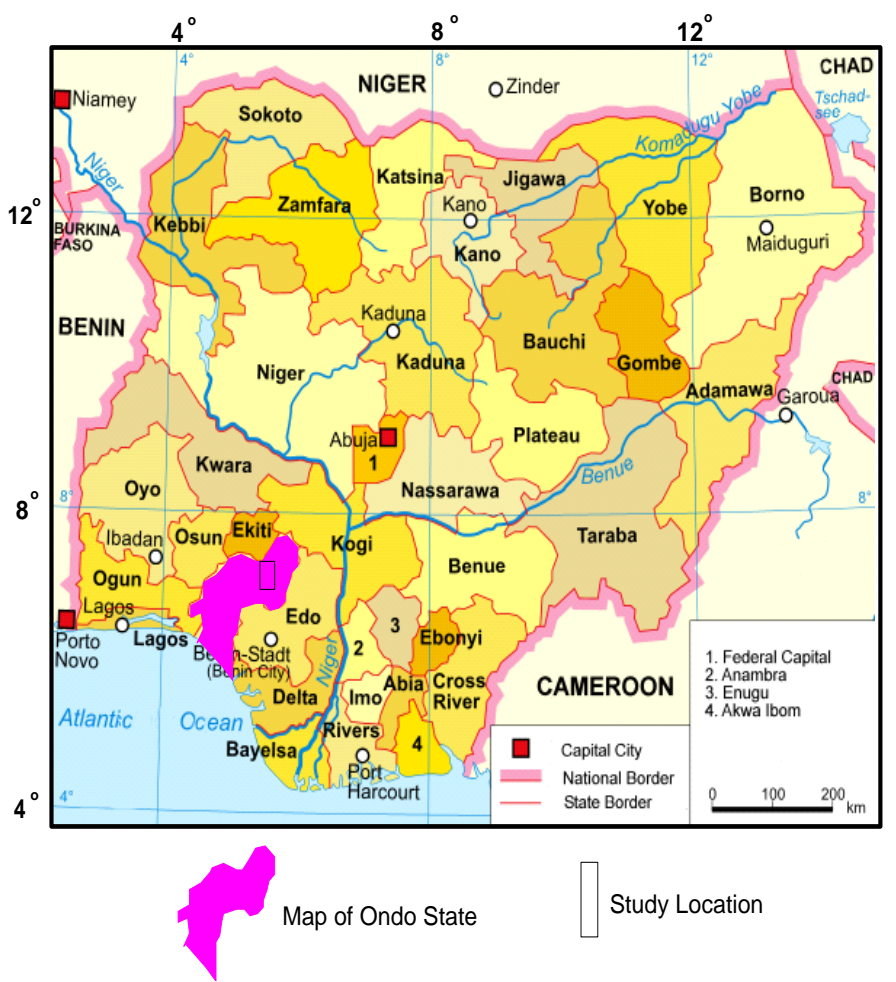

Fig. 1 Location of the Study Area on the Map of Nigeria

\section{MATERIAL AND METHODS}

The study entails geophysical survey, geotechnical investigations, and static water level determination. Before the field surveys, desktop and reconnaissance studies were conducted, followed by geologic study of rocks especially outcrops. Geotechnical investigation involves collection of five (5) disturbed representative samples at every $1 \mathrm{~km}$ along the roadway (Fig. 6). Properties tested geochemical and geotechnical tests. The geotechnical tests include the particle size 


\title{
International Advanced Research Journal in Science, Engineering and Technology
}

\author{
Vol. 7, Issue 4, April 2020
}

distribution, Atterberg limits, strength, specific gravity, consolidation test, shear test, California Bearing Ratio. Electrical resistivity technique was employed in studying the general geological subsurface lithology and structure [5] along one traverse of length $120 \mathrm{~m}$. The geophysical investigation was carried out using the Vertical Electrical Sounding (VES) with Schlumbeger types of electrode configuration. The collected soil samples from each horizon of the profiles were analyzed at the soil Engineering Geological laboratory of Federal University of Technology, Akure, Ondo State. The soil samples were geotechnically tested according to the BS 1377 [6] and ASTM [7] procedures. Moisture content (D2216), Atterberg limits (D4318), Particle size analysis (D422), Oedometer test (D2435), compaction (D1557), California Bearing Ratio test (D1883) and confined compressive test.

The chemical analysis was also carried out on the samples to determine the mineral oxides that were present in each sample. The sample were initially sieved using $2 \mathrm{~mm}$ sieve and $2 \mathrm{~g}$ of the sieved sample was taken, after which they were put into digesting tube and digested using and $\mathrm{HCl}$, then with $\mathrm{HClO}_{4}$ and $\mathrm{H}_{2} \mathrm{O}_{2}$. The samples were heated to dryness and make up with distilled water in a $100 \mathrm{ml}$ volumetric flask. The resultant solution was analyzed using X-ray fluorescence and Atomic Absorption Spectrophotometer (AAS). The silicon oxide and Aluminium oxide were analyzed with nitrous oxide while Iron-oxide with oxyacetylene. $\mathrm{P}_{2} \mathrm{O}_{5}$ and $\mathrm{TiO}_{2}$ were determined by a colorimetric method. The steps were repeated for the remaining samples, and the samples were subsequently allowed to stand for at least one hour in the solutions while they were frequently stirred. The extent to which a residual soil has been laterized may be measured by the ratio of silica $\left(\mathrm{SiO}_{2}\right)$ remaining in the soil (except for discrete pebbles of free quartz that may remain) to the amount of $\mathrm{Fe}_{2} \mathrm{O}_{3}$ and $\mathrm{Al}_{2} \mathrm{O}_{3}$ that has accumulated. The silica: sesquioxide ratio (Se) as shown in equation 1 , has served as a basis for classification of residual soils (Table 3). Ratios less than 1.33 have sometimes been considered indicative of true laterites, those between 1.33 and 200 of lateritic soils, and those greater than 2.00 of non-lateritic tropically weathered soils. An easy way to comply with the conference paper formatting requirements is to use this document as a template and simply type your text into it.

$$
S_{e}=\frac{\mathrm{SiO}_{2}}{\mathrm{Al}_{2} \mathrm{O}_{3}+\mathrm{Fe}_{2} \mathrm{O}_{3}}
$$

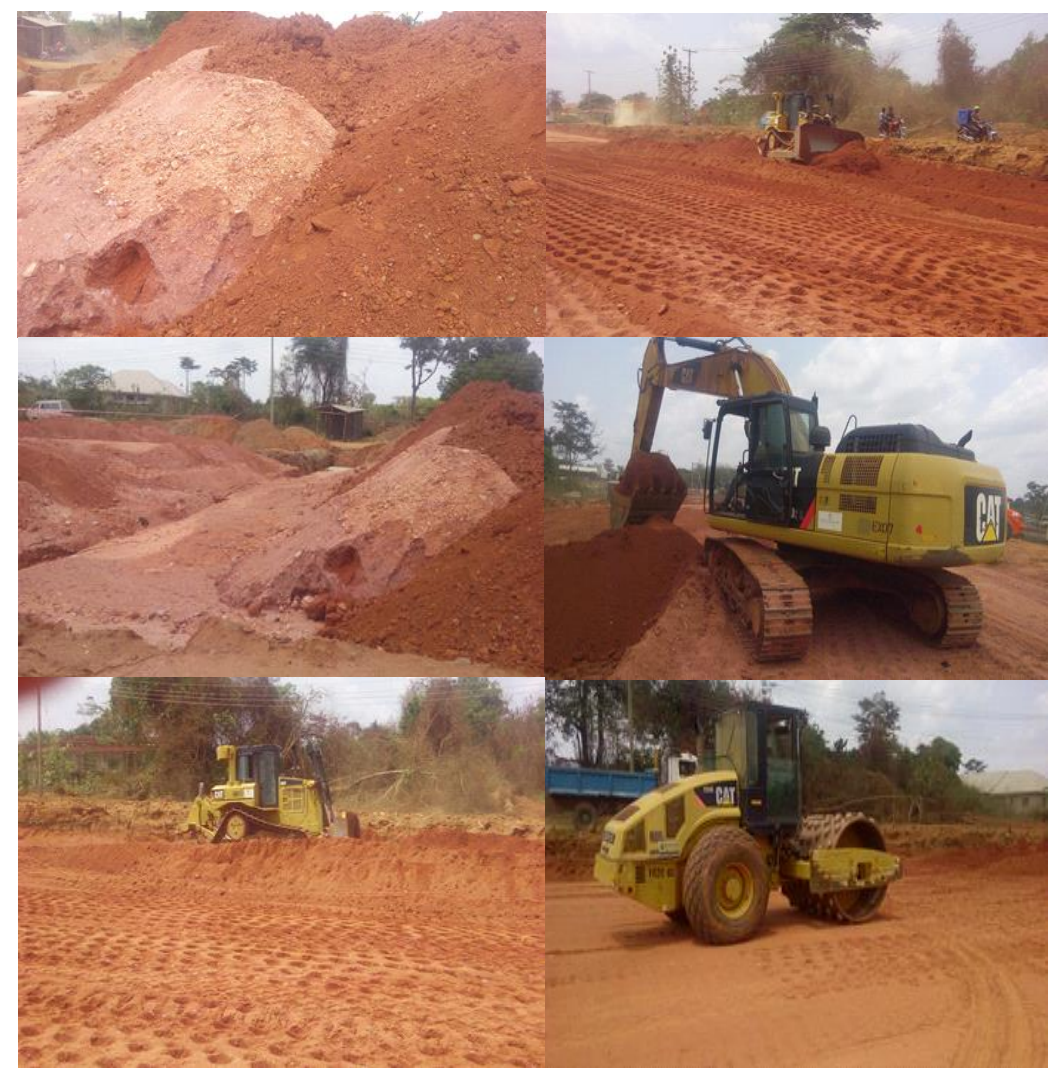

Fig. 2 Some of Site photographs taken along the roadway showing different construction processes and machine/equipment. 
International Advanced Research Journal in Science, Engineering and Technology

Vol. 7, Issue 4, April 2020

TABLE I DESCRIPTION OF SOIL ASSOCIATIONS IN THE STUDY AREA (ADAPTED FROM [8])

\begin{tabular}{|c|c|c|c|c|}
\hline S/N & $\begin{array}{l}\text { Soil } \\
\text { Association }\end{array}$ & Parent Rock & Drainage & Property/Characteristics \\
\hline 1 & IWO & $\begin{array}{l}\text { Coarse grained } \\
\text { Granites and } \\
\text { Gneisses }\end{array}$ & Well Drained & $\begin{array}{l}\text { Coarse textured, greyish brown, sandy to } \\
\text { fairly clayey soils, overlying weathered } \\
\text { rock material. Fresh rock at depths of } 7 \\
\text { to } 9 \text { feet, shallower in steep slopes. } \\
\text { Fairly frequent rock outcrop }\end{array}$ \\
\hline 2 & ONDO & $\begin{array}{l}\text { Medium grained } \\
\text { Granites and } \\
\text { Gneisses }\end{array}$ & Well Drained & $\begin{array}{l}\text { Medium to fine textured, orange brown } \\
\text { to brownish red, fairly clayey soils } \\
\text { overlying orange, brown and red mottled } \\
\text { clay. Fresh rock at depths of } 10-14 \text { feet; } \\
\text { occasionally rock outcrop. }\end{array}$ \\
\hline 3 & OKEMESI & $\begin{array}{l}\text { Quartz Schist } \\
\text { and Gneisses }\end{array}$ & Well Drained & $\begin{array}{l}\text { Very coarse textured, gravelly, pale } \\
\text { grayish brown to brown, usually sand } \\
\text { soils. Often very shallow over quartz } \\
\text { rubble, associated with a topography of } \\
\text { steep sided elongated ridges }\end{array}$ \\
\hline
\end{tabular}

\section{RESULTS AND DISCUSSION}

A.

Geochemical Analysis

The basic quality and performance selection requirements for fill material can be considered as placed stability; resistance to erosion, degradability and workability which depends on the mineralogical make-up of the soil [10]. The result of chemical analysis showing the different oxide forms of the major elements contained in the soil samples, and silica-sesquioxide ratio is presented in Table 3. The samples are well dominated (in ascending order) by $\mathrm{SiO}_{2}-\mathrm{Fe}_{2} \mathrm{O}_{3}$ $\mathrm{Al}_{2} \mathrm{O}_{3}$ with a little over $95 \%$ of the materials being characterized by these three elements oxide. The remaining less than $5 \%$ of the composition is dominated by $\mathrm{Na}_{2} \mathrm{O}$ and $\mathrm{K}_{2} \mathrm{O}$. The $\mathrm{SiO}_{2}$ varies between $45.30-47.10 \% . \mathrm{Fe}_{2} \mathrm{O}_{3}$ and $\mathrm{Al}_{2} \mathrm{O}_{3}$ of the samples range from $25.00-28.32 \%$ and $21.4-25.40 \%$ respectively. The $\% \mathrm{Na}_{2} \mathrm{O}$ and $\mathrm{K}_{2} \mathrm{O}$ concentrations also vary between $1.11-1.19$ and $1.23-1.68$ respectively. All the samples show high concentrations of $\mathrm{SiO}_{2}, \mathrm{Fe}_{2} \mathrm{O}_{3}$, and $\mathrm{Al}_{2} \mathrm{O}_{3}$ with little or no variation.

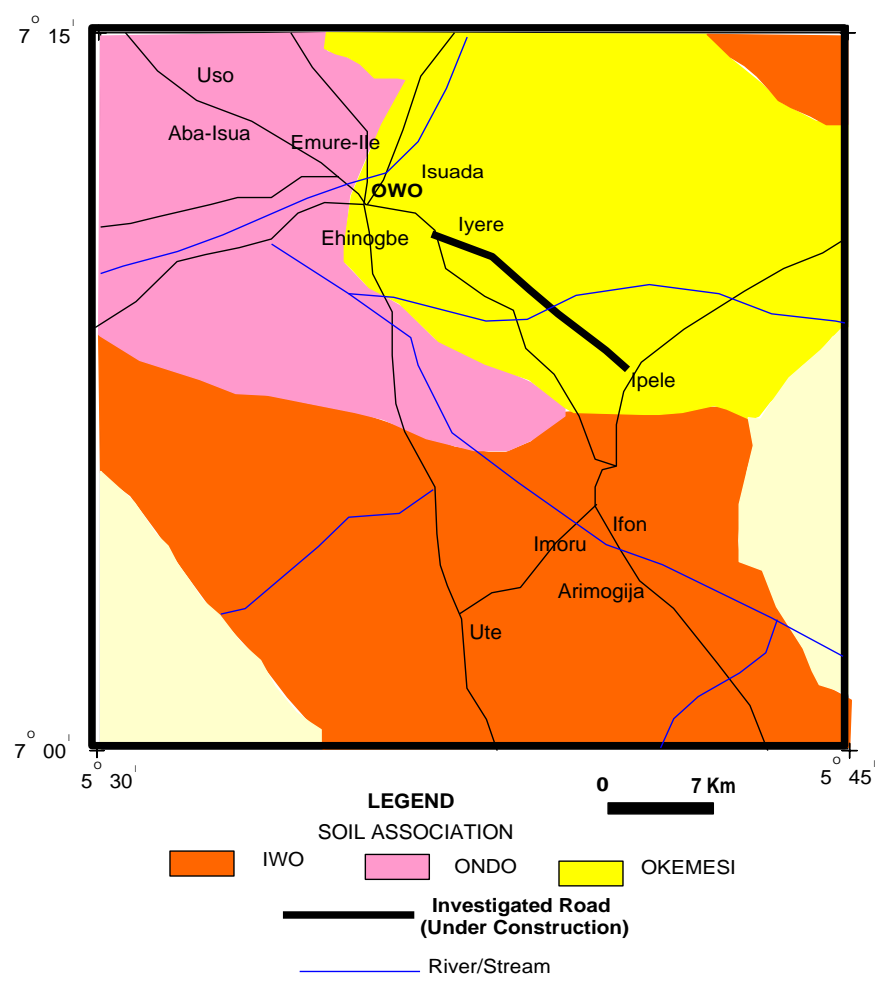

Fig. 3 Soil map around the Study Area (extracted from [8]) 
International Advanced Research Journal in Science, Engineering and Technology

Vol. 7, Issue 4, April 2020

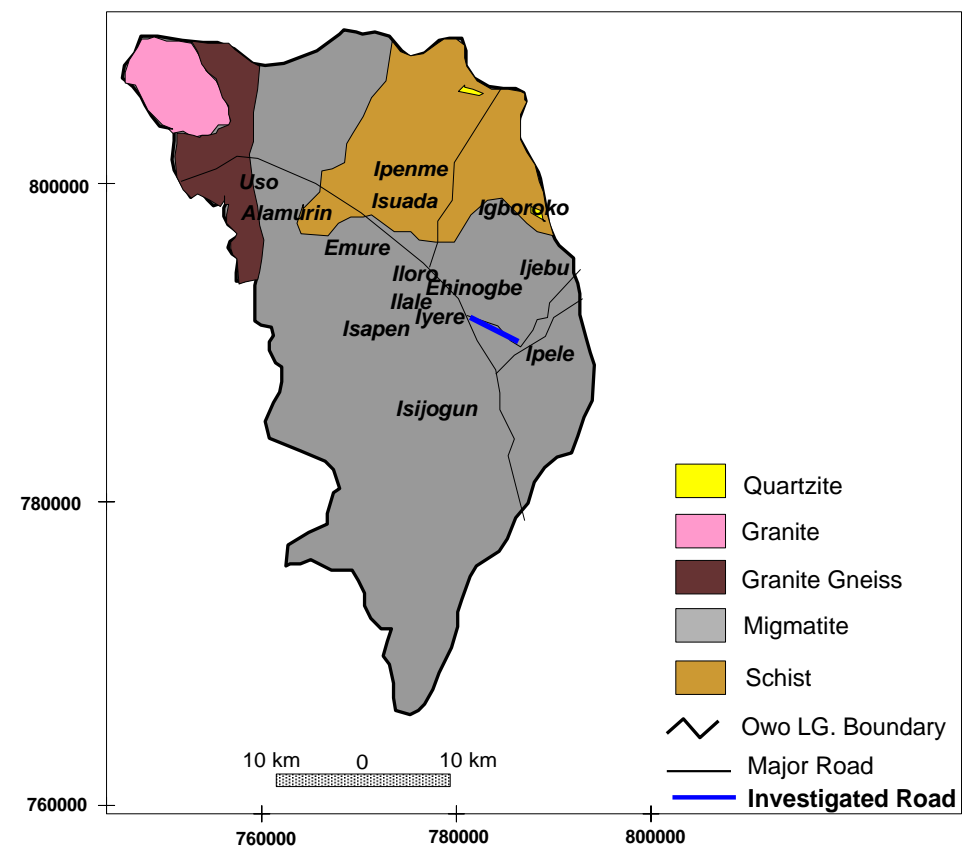

Fig. 4 Geological map of the Study Area (modified after [9])

TABLE 2 BASIC CLASSIFICATION OF METAMORPHIC ROCKS

\begin{tabular}{ll}
\hline Geotechnical Grouping & Typical Rock Type \\
\hline A. Isotropic & Massive Quartzite \\
& Marble \\
& Hornfels \\
B. Moderately $\quad$ Gneiss \\
Anisotropic & Bedded Quartzite \\
& Amphibolite \\
C. Strongly & Shale/Slate \\
Anisotropic & Phyllite \\
& Schist \\
\hline
\end{tabular}

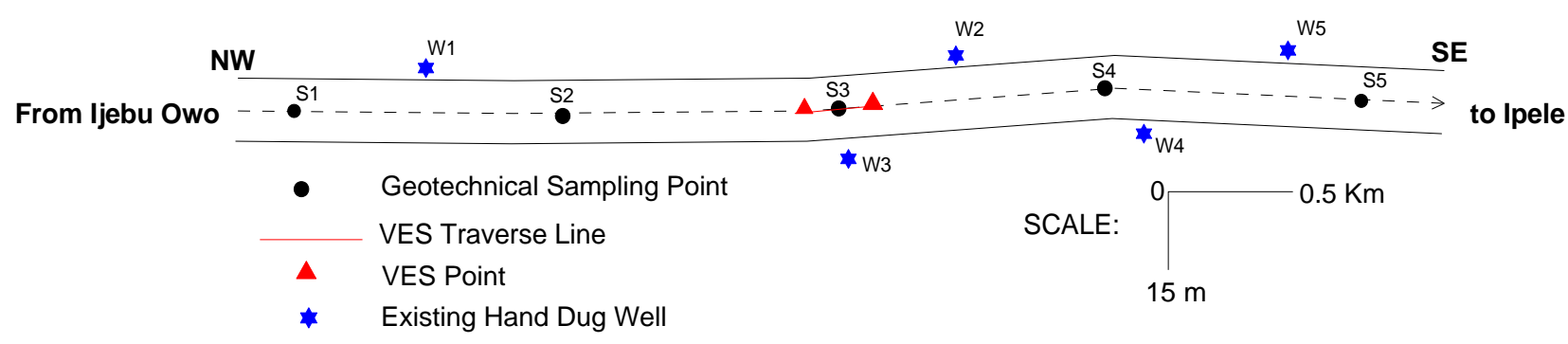

Fig. 5 Simplistic Sketch of Data Acquisition Map for the Study

TABLE 3 ClasSIFICATION OF SOIL BASED ON SILICA : SESQUIOXIDE

\begin{tabular}{|l|l|}
\hline Soil Type & Sesquioxide \\
\hline Laterite Soil & 1.33 or less \\
\hline Lateritic Soil & $1.33-2.00$ \\
\hline Non-Laterite & 2.00 and over \\
\hline
\end{tabular}




\section{International Advanced Research Journal in Science, Engineering and Technology}

Vol. 7, Issue 4, April 2020

TABLE 4 RESULT OF THE CHEMICAL ANALYSIS OF THE LATERITIC SOIL SAMPLES

\begin{tabular}{|l|l|l|l|l|l|}
\hline $\begin{array}{l}\text { Oxides } \\
(\%)\end{array}$ & $\mathbf{S 1}$ & $\mathbf{S 2}$ & $\mathbf{S 3}$ & $\mathbf{S 4}$ & $\mathbf{S 5}$ \\
\hline $\mathrm{MgO}$ & 0.23 & 0.22 & 0.22 & 0.21 & 0.22 \\
\hline $\mathrm{Al}_{2} \mathrm{O}_{3}$ & 25.40 & 24.39 & 22.74 & 21.4 & 22.56 \\
\hline $\mathrm{SiO}_{2}$ & 45.30 & 46.20 & 45.60 & 46.80 & 47.10 \\
\hline $\mathrm{P}_{2} \mathrm{O}_{5}$ & 0.00 & 0.00 & 0.11 & 0.01 & 0.11 \\
\hline $\mathrm{Na}_{2} \mathrm{O}$ & 1.19 & 1.16 & 1.12 & 1.11 & 1.15 \\
\hline $\mathrm{k}_{2} \mathrm{O}$ & 1.25 & 1.68 & 1.41 & 1.23 & 1.43 \\
\hline $\mathrm{CaO}$ & 0.17 & 0.26 & 0.24 & 0.21 & 0.22 \\
\hline $\mathrm{TiO}_{2}$ & 0.70 & 0.90 & 0.63 & 0.53 & 0.81 \\
\hline $\mathrm{V}_{2} \mathrm{O}_{5}$ & 0.11 & 0.09 & 0.13 & 0.11 & 0.13 \\
\hline $\mathrm{Cr}_{2} \mathrm{O}_{3}$ & 0.03 & 0.05 & 0.05 & 0.04 & 0.05 \\
\hline $\mathrm{MnO}$ & 0.03 & 0.05 & 0.05 & 0.03 & 0.02 \\
\hline $\mathrm{Fe}_{2} \mathrm{O}_{3}$ & 25.50 & 25.00 & 27.70 & 28.32 & 26.20 \\
\hline $\mathrm{S}_{\mathrm{e}}$ & 0.89 & 0.93 & 0.90 & 0.94 & 0.96 \\
\hline $\mathrm{Class}$ & $\begin{array}{l}\text { True } \\
\text { Laterite }\end{array}$ & $\begin{array}{l}\text { True } \\
\text { Laterite }\end{array}$ & $\begin{array}{l}\text { True } \\
\text { Laterite }\end{array}$ & $\begin{array}{l}\text { True } \\
\text { Laterite }\end{array}$ & $\begin{array}{l}\text { True } \\
\text { Laterite }\end{array}$ \\
\hline
\end{tabular}

The enrichment of $\mathrm{Fe}_{2} \mathrm{O}_{3}$ in each of the samples can be attributed to chemical weathering of mafic mineral composition of the parent rock and ferruginization of Fe-bearing minerals [11]. Also enrichment of $\mathrm{Al}_{2} \mathrm{O}_{3}$ can be attributed to the weathering alteration of feldspar to clay mineral causing leaching of $\mathrm{Al}_{2} \mathrm{O}_{3}$ by infiltrating acid rain/recharge water into the ground. This implies that the subgrade (imported) soil must been from the same parent rock and suggestive of rock rich in aluminosilicates minerals. Silica-Sesquioxide ratio of the ranges from 0.89 to 0.96 and classified as True Laterite according to [12] laterite classification.

\section{B. $\quad$ Vertical Electrical Sounding}

The geoelectric section along the traverse established is shown in Figure 6. Lithologically, it is made of topsoil, weathered layer, confined fracture basement, and basement rock. The topsoil is characterized by resistivity ranging from 298 - 924 ohm-m and thickness varying from 3.1 - $8.2 \mathrm{~m}$ and composed of clay sand and laterite. The weathered layer underlain the topsoil, and has resistivity ranging between $943 \mathrm{ohm}-\mathrm{m}$ and $1264 \mathrm{ohm}-\mathrm{m}$, indicating a lateritic rich weathered layer. The thickness of the weathered layer ranges from 1.3 to $2.4 \mathrm{~m}$. The fractured basement delineated is confined within the fresh basement and show low fracture density with thickness less than $5 \mathrm{~m}$, and resistivity range of $298-443$ ohm-m. The fresh basement is characterized with resistivity values ranging from $765-943 \mathrm{ohm}-\mathrm{m}$. Therefore using Table 5 classification, the topsoil along this traverse can be regarded as moderately competent/competent soil material to host and support the under-constructed pavement.

\section{Geotechnical Analysis}

Table 6 presents the summary of the geotechnical results obtained from five samples. Grain size analysis can be used to characterize the subsoil material for engineering foundation, which can serve as a guide to the engineering performance of the soil type and also provides a means by which soils can be identified quickly. The particle size distribution curves obtained from the study area are presented in Table 5. The gravel and sand contents vary from $2.0-2.7 \%$ and $70.5-$ $75.4 \%$ respectively. The $\%$ silt and clay of the soil samples range from 12 to $18.9 \%$ and 7.3 to $13.2 \%$. The composition of the samples is dominated by sand and silt (SM). The Casangrade plasticity shows that the fines in the samples is dominated by silt of intermediate plasticity except sample S1 which is characterized by clay of intermediate plasticity or compressibility. Most of the soil samples are plotted within the Kaolinite clay mineralogy group. Kaolinite is formed by the alteration of feldspars, feldspathoids and other aluminium silicates due to hydrothermal action. Weathering under acidic conditions is also responsible for kaolinization [14]. The plasticity of clay soil is influenced by the amount of its clay fraction and the type of clay minerals present, since the amount of attracted water held in a soil is influenced by clay minerals [15]. Kaolinite is the chief clay mineral in most residual and transported clays, is important in shales, and is found in variable amounts in fireclays, laterites and are associated with acid igneous rocks such as granites, granodiorites and tonalites, and with gneisses and granulites. Sample S1 is mineralogically close to illite, which develops as an alteration product of feldspars, micas or ferromagnesian silicates upon weathering or may form from other clay minerals during diagenesis. Like kaolinite, illite also may be of hydrothermal origin. The development of illite, both under weathering and by hydrothermal processes, is favoured by an alkaline environment. 
International Advanced Research Journal in Science, Engineering and Technology

Vol. 7, Issue 4, April 2020

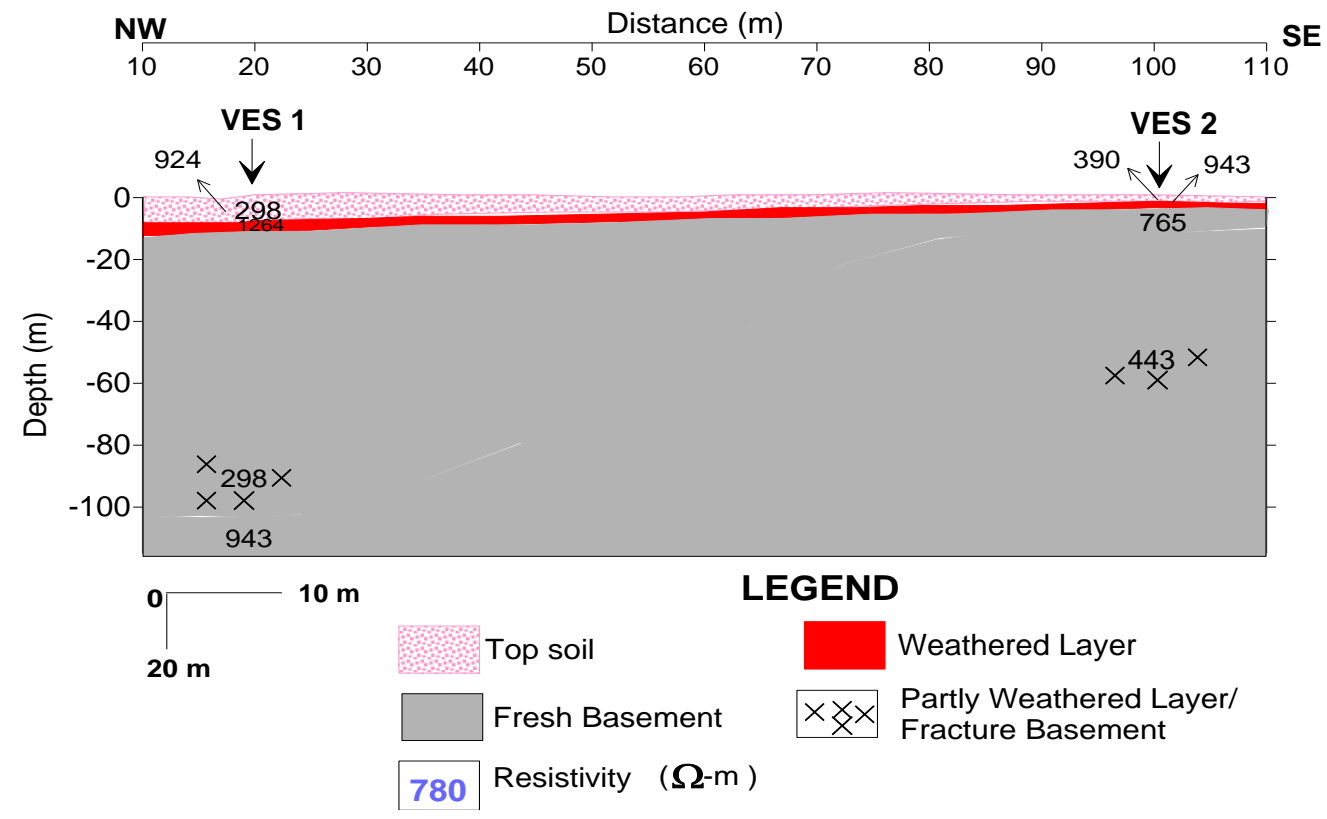

Fig. 6 Geoelectric Section along a segment of the Highway

TABLE 5 RATING OF SUBSOIL COMPETENCE USING RESISTIVITY VALUES (ADAPTED FROM [13])

\begin{tabular}{|l|l|l|}
\hline App. resistivity range (ohm-m) & Lithology & Competence rating \\
\hline$<100$ & Clay & Incompetent \\
\hline $100-350$ & Sandy clay & Moderately competent \\
\hline $350-750$ & Clayey sand & Competent \\
\hline$>750$ & Sand/Laterite/Crystalline Rock & Highly competent \\
\hline
\end{tabular}

TABLE 6 SUMmary OF GeOTECHNICAL PROPERTIES OF THE ANALYZED SOIL SAMPLES

\begin{tabular}{|l|l|l|l|l|l|}
\hline Tests/Sample & S1 & S2 & S3 & S4 & S5 \\
\hline \% Gravel & 2.4 & 2.7 & 2.0 & 2.4 & 2.3 \\
\hline \% Sand & 72.4 & 70.5 & 73.2 & 75.4 & 71.5 \\
\hline \% Silt & 12.0 & 15.9 & 16.1 & 14.3 & 18.9 \\
\hline \% Clay & 13.2 & 10.8 & 8.7 & 7.9 & 7.3 \\
\hline Specific Gravity & 2.68 & 2.66 & 2.65 & 2.66 & 2.65 \\
\hline Liquid Limit $(\%)$ & 44.4 & 43.4 & 45.2 & 42.6 & 47.8 \\
\hline Plastic Limit $(\%)$ & 21.3 & 30.7 & 30.1 & 28.4 & 31.6 \\
\hline Plasticity Index (\%) & 23.1 & 12.7 & 15.1 & 14.2 & 16.2 \\
\hline OMC (\%) & 12.3 & 12.5 & 12.6 & 13.1 & 11.8 \\
\hline MDD $\left(\mathrm{Kg}^{3}\right)$ & 1726 & 1743 & 1748 & 1725 & 1771 \\
\hline CBR $(\%)($ unsoaked) & 69 & 64 & 73 & 69 & 74 \\
\hline$C_{\mathrm{v}}\left(\mathrm{m}^{2} / \mathrm{yr}\right)$ & 0.31978 & 0.33056 & 0.31431 & 0.33812 & 0.30988 \\
\hline UCS $($ Kpa) & 385.10 & 420.50 & 392.40 & 405.70 & 382.20 \\
\hline Shear strength (Kpa) & 177.55 & 199.60 & 181.10 & 189.20 & 175.60 \\
\hline USCS Group & SC & SM & SM & SM & SM \\
\hline AASHTO Classification & A-2-7 & A-2-6 & A-2-7 & A-2-6 & A-2-7 \\
\hline USCS Rating & Fair to good & Fair to good & Fair to good & Fair to good & Fair to good \\
\hline Casagrande plasticity & CI & MI & MI & MI & MI \\
\hline AASHTO Rating & Good & Good & Good & Good & Good \\
\hline
\end{tabular}

Therefore using Table 7, the soils are rated as "fair to good" as pavement subgrade material. This is also corroborated by the AASHTO classification in Figure 7 which shows that the samples have good properties suitable as subgrade material. The values of specific gravity of the samples range between $2.65-2.68$. According to [16], the standard range of value of specific gravity of soils lies between 2.60 and 2.80; these values are considered normal. Specific gravity is known to correlate with mechanical strength of soil and may be used as a basis for selecting suitable highway pavement 


\section{International Advanced Research Journal in Science, Engineering and Technology}

Vol. 7, Issue 4, April 2020

construction materials particularly when used with other pavement construction materials. The liquid limit (LL) values range between 42.6 to $47.8 \%$, plastic limits (PL) range between 21.3 to $31.6 \%$ and plasticity index (PI) is between 12.7 to $23.1 \%$. The Federal Ministry of Works and Housing [17] recommends LL of 50\% (max.), PI of 20\% as (max.), plastic limit of $30 \%$ (max.) and \% Fines of 35 maximum for highway subgrade soil. Hence the soils satisfy this requirements as subgrade material. Compaction is concerned with relationships between moisture content, applied effort and density. Compaction is undertaken on the road to enhance the mass density and hence the strength, rigidity and durability of placed materials [18]. In the laboratory compaction testing is undertaken to predict moisture density responses of a material to applied effort and to provide a reference with which to control on-site compaction during construction. The maximum dry density (MDD) for the soil samples varied between 1725 and $1771 \mathrm{~kg} / \mathrm{m}^{3}$ at standard proctor compaction energy while the optimum moisture content (OMC) range between 12.3 and 13.1\%. An important part of the grading of the site often includes the compaction of fill. Compaction is defined as the densification of a fill by mechanical means. This physical process of getting the soil into a dense state can increase the shear strength, decrease the compressibility, and decrease the permeability of the soil. All the soil samples have moderately high MDD at low OMC. The California Bearing Ratio (CBR) is an empirical test employed in road engineering as an index of compacted material strength and rigidity, corresponding to a defined level of compaction. All compacted samples show unsoaked CBR values ranging between 64 and 74\%. The Federal Ministry of Works and Housing [17] recommends a California Bearing Ratio of greater than $10 \%$ for subgrade materials.

TABLE 7 CHARACTERISTICS OF COMPACTED SUBGRADE FOR ROADS AND AIRFIELDS [19]

\begin{tabular}{|c|c|c|c|c|}
\hline $\begin{array}{l}\text { Major } \\
\text { Division }\end{array}$ & Subdivision & $\begin{array}{l}\text { USCS } \\
\text { Symbol }\end{array}$ & Name & $\begin{array}{l}\text { Value as } \\
\text { Subgrade }\end{array}$ \\
\hline \multirow{8}{*}{$\begin{array}{l}\text { Coarse- } \\
\text { grained } \\
\text { soils }\end{array}$} & \multirow{4}{*}{$\begin{array}{l}\text { Gravel \& } \\
\text { Gravelly } \\
\text { soils }\end{array}$} & GW & $\begin{array}{l}\text { Well graded gravels or gravel-sand mixtures, little or no } \\
\text { fines }\end{array}$ & Excellent \\
\hline & & GP & Poorly graded gravels or gravelly sands, little or no fines & Good to excellent \\
\hline & & GM & Silty gravels, gravel-sand-silt mixtures & Good to excellent \\
\hline & & GC & Clayey gravels, gravel-sand-clay mixtures & Good \\
\hline & \multirow{4}{*}{$\begin{array}{l}\text { Sand and } \\
\text { Sandy soils }\end{array}$} & SW & Well-graded sands or gravelly sands, little or no fines & Good \\
\hline & & SP & Poorly graded sands or gravelly sands, little or no fines & Fair to good \\
\hline & & SM & Silty sands, sand-silt mixtures & Fair to good \\
\hline & & $\mathrm{SC}$ & Clayey sands, sand-clay mixtures & Poor to fair \\
\hline \multirow{6}{*}{$\begin{array}{l}\text { Fine- } \\
\text { grained } \\
\text { soils }\end{array}$} & \multirow{3}{*}{$\begin{array}{l}\text { Silts and } \\
\text { clays with } \\
\text { liquid limit } \\
\text { less than } 50\end{array}$} & ML & Inorganic silts, rock flour, silts of low plasticity & Poor to fair \\
\hline & & CL & $\begin{array}{l}\text { Inorganic clays of low plasticity, gravelly clays, sandy } \\
\text { clays etc. }\end{array}$ & Poor to fair \\
\hline & & OL & Organic silts and organic clays of low plasticity & Poor \\
\hline & \multirow{3}{*}{$\begin{array}{l}\text { Silts and } \\
\text { clays with } \\
\text { liquid limit } \\
\text { greater than } \\
50\end{array}$} & MH & Inorganic silts, micaceous silts, silts of high plasticity & Poor \\
\hline & & $\mathrm{CH}$ & $\begin{array}{l}\text { Inorganic clays of high plasticity, fat clays, silty clays } \\
\text { etc. }\end{array}$ & Poor to fair \\
\hline & & $\mathrm{OH}$ & Organic clays, organic silts, with high plasticity & Poor to very poor \\
\hline Peat & & PT & Peat and other highly organic soils & Not suitable \\
\hline
\end{tabular}

\begin{tabular}{|c|c|c|c|c|c|c|c|c|c|c|c|}
\hline \multirow{3}{*}{$\begin{array}{l}\text { General Classification } \\
\text { Group Classification }\end{array}$} & \multicolumn{5}{|c|}{$\begin{array}{l}\text { Granulary Materials } \\
\text { (35\% or less passing No. 200) }\end{array}$} & & \multicolumn{5}{|c|}{$\begin{array}{l}\text { Silt-Clay Materials } \\
\text { (More } 35 \% \text { or less passing No. 200) }\end{array}$} \\
\hline & \multicolumn{2}{|c|}{$A-1$} & \multirow[b]{2}{*}{ A-3 } & \multicolumn{3}{|c|}{ A-2 } & \multirow[b]{2}{*}{ A-2-7 } & \multirow[b]{2}{*}{ A-4 } & \multirow[b]{2}{*}{ A-5 } & \multirow[b]{2}{*}{ A-6 } & \multirow{2}{*}{$\begin{array}{l}A-7 \\
A-7-5 \\
A-7-6 \\
\end{array}$} \\
\hline & A-1-a & $A-1-b$ & & A-2-4 & $A-2-5$ & A-2-6 & & & & & \\
\hline \multicolumn{12}{|c|}{ Sieve analysis, percentage passing: } \\
\hline No. $10(2.00 \mathrm{~mm})$ & $50 \max$ & $\cdots \cdots .$. & $\cdots \cdots . .$. & $\ldots \ldots .$. & ....... & $\cdots \cdots$ & $\ldots \ldots .$. & $\ldots \ldots .$. & $\cdots \cdots$ & $\ldots \ldots .$. & -....... \\
\hline No. $40(0.425 \mathrm{~mm})$ & $30 \max$ & $50 \max$ & $51 \max$ & -....... & 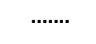 & $\cdots \cdots \cdot$ & $\ldots \cdots$ & $\ldots \ldots$. & $\ldots \ldots$ & $\ldots \ldots$ & $\ldots \ldots .$. \\
\hline No. $200(0.075 \mathrm{~mm})$ & $15 \max$ & $25 \max$ & $10 \max$ & $35 \max$ & $35 \max$ & $35 \max$ & $35 \max$ & $35 \max$ & $36 \mathrm{~min}$ & $36 \mathrm{~min}$ & $36 \mathrm{~min}$ \\
\hline \multicolumn{12}{|c|}{ Characteristics of fraction passing } \\
\hline \multicolumn{12}{|c|}{ No. $40(0.425 \mathrm{~mm})$} \\
\hline Liquid Limit & $\cdots \cdots$ & $\cdots \cdots$ & $\cdots \cdots .$. & $40 \max$ & $40 \mathrm{~min}$ & $40 \max$ & $41 \mathrm{~min}$ & $40 \max$ & $41 \mathrm{~min}$ & $40 \max$ & $41 \mathrm{~min}$ \\
\hline Plasticity Index & $6 \max$ & & N.P & $10 \max$ & $10 \max$ & $11 \mathrm{~min}$ & $11 \mathrm{~min}$ & $10 \max$ & $10 \max$ & $11 \mathrm{~min}$ & $11 \mathrm{~min}$ \\
\hline $\begin{array}{l}\text { Usual types of significant } \\
\text { Materials }\end{array}$ & $\begin{array}{l}\text { Stone fra } \\
\text { Gravel an }\end{array}$ & $\begin{array}{l}\text { gments } \\
\text { hd Sand }\end{array}$ & $\begin{array}{l}\text { Fine } \\
\text { Sand }\end{array}$ & Silty - & Clayey & Gravel and & Sand & \multicolumn{2}{|c|}{ Silty Soils } & \multicolumn{2}{|c|}{ Clayey Soils } \\
\hline
\end{tabular}

Fig. 7 AASHTO Soil Classification and Rating [20] 


\title{
International Advanced Research Journal in Science, Engineering and Technology
}

\author{
Vol. 7, Issue 4, April 2020
}

The result shows that the California Bearing Ratio values of the soils are much higher than $10 \%$. Hence suitable as foundation material for road construction. The coefficient of consolidation $\left(\mathrm{C}_{\mathrm{v}}\right)$ for the soil samples ranges from 0.3099 - $0.3381 \mathrm{~m}^{2} / \mathrm{yr}$. Using Table 8 according to [21] the values of coefficient of consolidation $(\mathrm{Cv}) \mathrm{m}^{2} / \mathrm{yr}$ obtained for samples correspond to soils with low rate of consolidation. The shear strength of a soil is a basic geotechnical engineering parameter and is required for the analysis of foundations, earthwork, and slope stability problems. This is because of the nature of soil, which is composed of individual soil particles that slide (i.e., shear past each other) when the soil is loaded. The summary of the results of the unconfined compression test and shear strength are presented in Table 6. The unconfined compressive strength and shear strength of the tested soils range from $382.20-420.50 \mathrm{Kpa}$ and $177.55-199.60 \mathrm{Kpa}$ respectively. Considering the range of values of unconfined compressive strength in Table 8, consequently the soil samples fall within the range of $0.3-12.5 \mathrm{MPa}$ which is considered as hard - moderately hard soil. Also the range of values obtained for shear strength fall within the very stiff soil classification (Table 8). The shear strength of a soil is a basic geotechnical engineering parameter and is required for the analysis of foundations, earthwork, and slope stability problems [22], [23]. This is because of the nature of soil, which is composed of individual soil particles that slide (i.e., shear past each other) when the soil is loaded. Since soil fails as a result of shear, the soil samples have moderate internal resistance per unit area to resist failure and sliding along any plane inside it. Static water level (SWL) measured from open wells along the highway varies from $3.3 \mathrm{~m}$ to $5.5 \mathrm{~m}$ with an average of $4.3 \mathrm{~m}$. The hydraulic head measured with respect to sea level ranges between $337.7 \mathrm{~m}$ to $340.5 \mathrm{~m}$ (Table 9). Consequently, the SWL in the area is moderately low, therefore it may not seriously affect the subgrade. However excessive cut into the subsoil would lead to high water level situation which could compromise the integrity of the pavement structures.

TABLE 8 TyPiCAL VALUES OF THE COEFFICIENT OF CONSOLIDATION, GRADES OF UNCONFINED COMPRESSIVE

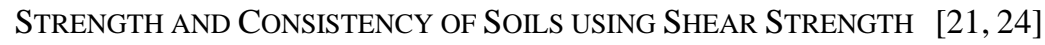

\begin{tabular}{|c|c|c|c|c|c|}
\hline $\begin{array}{l}\text { Coefficient of } \\
\text { Consolidation, } \mathrm{C}_{\mathrm{v}} \\
\left(\mathrm{m}^{2} / \text { year }\right)\end{array}$ & $\begin{array}{l}\text { Rate of } \\
\text { Consolidation }\end{array}$ & Description & $\begin{array}{l}\text { Approximate unconfined } \\
\text { compressive strength }\end{array}$ & Description & $\begin{array}{l}\text { Approximate } \\
\text { undrained } \\
\text { shear } \\
\text { strength } \\
\text { (Kpa) }\end{array}$ \\
\hline$<0.01$ & Very low & Very soft to soft & $36-300 \mathrm{Kpa}$ & Hard & Over 300 \\
\hline $0.1-1.0$ & Low & $\begin{array}{c}\text { Hard to } \\
\text { moderately hard }\end{array}$ & $0.3-12.5 \mathrm{MPa}$ & Very stiff & $150-300$ \\
\hline $1-10$ & Medium & $\begin{array}{c}\text { Moderately } \\
\text { strong to strong }\end{array}$ & $12.5-100 \mathrm{MPa}$ & Stiff & $75-150$ \\
\hline $10-100$ & High & $\begin{array}{l}\text { Strong to very } \\
\text { strong }\end{array}$ & Greater than $100 \mathrm{MPa}$ & Firm & $40-75$ \\
\hline$>100$ & Very high & & & $\begin{array}{c}\text { Soft } \\
\text { Very soft }\end{array}$ & $\begin{array}{c}20-40 \\
\text { Less than } 20\end{array}$ \\
\hline
\end{tabular}

TABLE 9 HydRo-GEOLOGICAL FIELD MEASUREMENTS OBTAINED ALONG THE HighWAY

\begin{tabular}{|l|l|l|l|l|l|}
\hline S/No. & Easting & Northing & Elevation $(\mathrm{m})$ & Static water level (m) & Hydraulic Head (m) \\
\hline WL-1 & 780089 & 810057 & 341 & 3.3 & 337.7 \\
\hline WL-2 & 780061 & 810713 & 343 & 4.9 & 338.1 \\
\hline WL-3 & 780458 & 810398 & 342 & 4.2 & 337.8 \\
\hline WL-4 & 780473 & 810584 & 344 & 3.8 & 340.2 \\
\hline WL-5 & 780632 & 810342 & 346 & 5.5 & 340.5 \\
\hline
\end{tabular}

\section{CONCLUSION}

The study was to assess the engineering characteristics of the subgrade used for flexible pavement construction along Iyere - Ipele, Southwestern Nigeria. Even though the road was still under construction as at the time of conducting this research. The chief-engineer on site (in charge of the highway) was very offensive to the researcher (with the thought that the researcher was trying to spy design parameters of the highway) especially during the reconnaissance survey and sample collection. Therefore this limited the samples collected to five and one traverse established for VES survey. All the samples show high concentrations of $\mathrm{SiO}_{2}, \mathrm{Fe}_{2} \mathrm{O}_{3}$, and $\mathrm{Al}_{2} \mathrm{O}_{3}$ with little or no variation. Silica-Sesquioxide ratio of the ranges from 0.89 to 0.96 and classified as True Laterite. The soils are predominantly silty sand with intermediate plasticity and characterized with moderate shear strength $(150-200 \mathrm{kpa})$, and unconfined compressive strength $(300-$ 


\section{International Advanced Research Journal in Science, Engineering and Technology}

Vol. 7, Issue 4, April 2020

420kpa). The soils clay mineralogy is basically kaolinite except sample S1 which shows near illite-group. The geoelectric section shows topsoil that is characterized by resistivity ranging from $298-924$ ohm-m and thickness varying from $3.1-8.2 \mathrm{~m}$ and composed of clay sand and laterite. The result of the geoelectric correlate well with the soils' laboratory geotechnical properties. The soils satisfy the recommended values of consistency limits, and California Bearing Ratio. The AASHTO classification rates the soils as good subgrade, while USCS rating is fair good. Therefore judging from the results obtained the soils are suitable as subgrade/foundation pavement material.

\section{REFERENCES}

[1]. R.S. Millard, "Road building in the tropics. State of the Art Review," 1990

[2]. D. Croney, and J.N. Bulman, "The influence of climatic factors on the structural design of flexible pavements," 3rd Int. Conf. on Structural Design of Asphalt Pavements, London. 67-71, 1975.

[3]. O.J. Nnanna, F.O. Odoko, and S.O. Alade, "Highway Maintenance in Nigeria, Lessons from other countries," Research Department Occasional Paper Series, Central Bank of Nigeria, 2003.

[4]. W. Black, and N.W. Lister, "The strength of fill sub-grades, its prediction and relation to road performance," ICE Conf. on Clay Fills, pp. 3748, 1978 .

[5]. L.O. Momoh, O.J. Akintorinwa, and M.O. Olorunfemi, "Geophysical Investigation of Highway Failure - A Case Study from the Basement Complex Terrain of Southwestern Nigeria," Journal of Applied Sciences Research, 4(6): pp. 637-648, 2008.

[6]. British Standard Institution, "Methods of Test for Soils for Civil Engineering Properties (BS 1377)," British Standard Institution: London, UK. 143p, 1990.

[7]. ASTM, "Standard Test Methods for Classification of Soils for Engineering Purposes (D2487-85)," Annual Book of Standards, 1989.

[8]. A.J. Smith, and R.F. Montgomery, "Soils and land use in Central Western Nigeria," The Government of Western Nigeria, Ibadan Publication, 1962.

[9]. Geological Survey of Nigeria, "Geological Map of Southwestern Nigeria," Geological Survey Department, Ministry of Mines, Power and Steel, Nigeria, 1984.

[10]. J.K. Mitchell, "Fundamentals of Soil Behaviour," John Wiley \& Sons. 422pp, 1993

[11]. P.R. Vaughan, "Mechanical \& hydraulic properties of tropical lateritic \& saprolitic soils, particularly as related to their structure \& mineral components," Proc. 1st Int. Conf. Geomech in Trop. Lateritic \& Saprolitic Soils, Brasilia, 3, pp. 231-262, 1985.

[12]. F.J. Martin, H.C. Doyne, "Laterite and lateritic soils in Sierra Leone," Journal of Agricultural Science, 17, pp. 530-547, 1927.

[13]. A.I. Idornigie, M.O. Olorunfemi, A.A. Omitogun, "Electrical resistivity determination of subsurface layers, subsoil competence and soil corrosivity at an engineering site location in Akungba-Akoko, Southwestern Nigeria," Ife Journal of Science, 8(2): 159-177, 2006.

[14]. D.P. Krynine, and J.R. William, "Principles of Engineering Geology and Geotechnics," McGraw - Hill: New York, 159, 537p, 1957.

[15]. L.D. Wesley, "Some basic engineering properties of halloysite and allophane clays in Java, Indonesia," Geot. 23, pp. 471-494, 1973.

[16]. P.H. Wright, "Highway Engineering, Sixth Edition," John Willey and Sons: New York, 1986.

[17]. Federal Ministry of Works and Housing, "Nigerian general specifications for roads and bridges," Federal Highway Department, 2:145-284, 1997.

[18]. S.K. Garg, "Soil Mechanics and Foundation Engineering," 7th ed. Khanna Publishers: New Delhi. India. 673- 683, 2009.

[19]. U.S. Army, "The Unified Soil Classification System (USCS)," 1960.

[20]. AASHTO, "Guide for design of pavement structures. American Association of State Highway and Transportation Officials," Washington, DC, 1993.

[21]. T.W. Lambe, and R.V. Whitman, "Methods of Estimating Settlement and Soil Mechanics," S. I Version, John Wiley \& Son. Journal on Mechanics and Foundation Division American Society of Civil Engineering. Vol. 90, 42p. 1979.

[22]. C.O. Okogbue, "Evaluation of Strength Properties of Mineral Soil,” Nig. Journ. Min. and Geol., $22(1$ \& 2): 89 - $97,1985$.

[23]. R.A. Abeyeskera, C.W. Lovell, and L.E. Wood, "Stress Deformation and Strength Characteristics of a Compacted Shale Clay fills". Institution of Civil Engineers: London, UK.1-14, 1978.

[24]. F.G. Bell, Engineering Geology, 2nd Edition. Elsevier: London, UK. 207-248, 2007. 